\title{
Cinismo e preconceito: uma homologia com o fetichismo freudiano em The Authoritarian Personality
}

Cynicism and Prejudice: A Homology

with Freudian Fetishism

in The Authoritarian Personality

\author{
Virginia Helena Ferreira da Costa \\ Doutora pelo Departamento de Filosofia \\ Universidade de São Paulo[USP]/CNPq
}

\section{RESUMO}

O trabalho aborda o cinismo do tipo antropológico autoritário de The Authoritarian Personality em homologia com o fetichismo descrito por Freud. Metapsicologicamente, é trabalhado o problema da síntese do eu e cisão interna a tal instância, bem como a externalização do superego. Sendo este sujeito massificado e esclarecido, a assunção de discursos morais contraditórios na mesma estrutura psíquica possibilitaria a manutenção de preconceito e autoritarismo em ambientes democráticos mediante racionalizaçôes.

\section{PALAVRAS-CHAVE}

Democracia; Autoritarismo; Cinismo; Fetichismo.

\section{ABSTRACT}

The article addresses the cynicism of the authoritarian anthropological type on The Authoritarian Personality in homology with the fetishism described by Freud. Metapsychologically, we work on the ego-synthesis and ego-splitting problems, in addition to the superego externalization. As a massed and enlightened subject, the assumption of contradictory moral discourses in the same psychic structure would enable a maintenance of prejudice and authoritarianism in democratic environments through rationalizations.

\section{KEY WORDS}

Democracy; Authoritarianism; Cynicism; Fetishism. 


\section{0 cinismo em The Authoritarian Personality}

The Authoritarian Personality (1950) é uma pesquisa empírica de base teórica filosófica, psicanalítica e sociológica produzida sob financiamento do American Jewish Committee (AJC) de New York. Sendo somente uma de um conjunto de cinco pesquisas dirigidas por Horkheimer e Flowerman — conjunto intitulado Studies on Prejudice —, TAP foi escrito por Theodor W. Adorno e os pesquisadores de Berkeley Else Frenkel-Brunswik, Daniel J. Levinson e Nevitt Sanford. A questáo a partir da qual a obra se desenvolve aborda a possibilidade de repetição do genocídio de judeus: seria possível a ocorrência de algo similar ao que aconteceu no Terceiro Reich alemão nos Estados Unidos da América, isto é, em um ambiente democrático? Contudo, o livro que inicialmente estava mais voltado ao antissemitismo viu-se transformado em uma pesquisa sobre posicionamentos contra minorias diversas ${ }^{1}$, tendo como norte principal o preconceito de forma geral, ou ainda, o etnocentrismo.

O principal objetivo dos autores era encontrar quais seriam as gratificaçôes na economia emocional e pulsional subjetivas envolvidas na identificação com ideologias autoritárias. Na pesquisa, foram considerados potencialmente fascistas aqueles mais suscetíveis à propaganda ideológica autoritária e preconceituosa. Sendo pensado mais como uma atitude do que uma mera opiniáo, o apoio a tais ideologias poderia passar de um estado latente ou velado e muitas vezes não completamente consciente para, em momentos determinantes de crise social, uma defesa aberta e açóes violentas contra minorias.

Contudo, isso náo fez com que o ponto de vista de Adorno e de seus colegas encontrasse a origem do etnocentrismo em fatores psíquicos. Eles partiram do pressuposto segundo o qual o preconceito teria uma gênese socialmente determinada. Este princípio tornou específico o emprego da teoria psicanalítica freudiana no que concerne à interpretação das características da personalidade: ao abordarem a ocorrência ampla de determinados traços psíquicos, os autores os tomaram como resultados de influências culturais que culminaram em verdadeiras tipificaçóes antropológicas. Como vemos em uma carta de Horkheimer endereçada a Marcuse, de I7 de julho de I943:

Não preciso lhe dizer que não acredito na psicologia como meio de resolver um problema tão sério [como o antissemitismo]. Não mudei em nada meu ceticismo para com essa disciplina. Portanto, emprego [...] o termo psicologia para designar a antropologia, e antropologia no sentido da teoria do homem tal como ele se formou no contexto de uma sociedade antagonista. Minha intenção é estudar a presença do esquema de dominação na pretensa vida psicológica, tanto nos instintos quanto nos pensamentos dos homens. As próprias tendências das pessoas

I "Our study grew out of specific investigations into anti-Semitism. As our work advanced, however, the emphasis gradually shifted. We came to regard it as our main task not to analyze anti-Semitism or any other antiminority prejudice as a sociopsychological phenomenon per se, but rather to examine the relation of antiminority prejudice to broader ideological and characterological patterns. Thus anti-Semitism gradually all but disappeared as a topic of our questionnaire and in our interview schedule it was only one among many topics which had to be covered" (Adorno, I950b, p. 605). 
que as tornam receptivas à propaganda do terror são, elas mesmas, o resultado do terror, físico ou mental, da opressão em ato ou potencial. Se nós conseguirmos descrever os processos pelos quais a dominação exerce sua influência até nos domínios mais afastados do espírito, teremos feito um belo trabalho (Horkheimer apud Wiggershaus, 2002, p. 388).

Nesse sentido, eis como uma nova espécie antropológica foi concebida em TAP:

O tema central da obra é um conceito relativamente novo - o surgimento de uma espécie "antropológica" que chamamos de tipo autoritário de homem. Em contraste com o fanático do estilo mais antigo, ele parece combinar as ideias e habilidades típicas de uma sociedade altamente industrializada com crenças irracionais ou antirracionais. Ele é ao mesmo tempo esclarecido e supersticioso, orgulhoso de ser individualista e em constante medo de não ser como todos os outros, zeloso de sua independência e inclinado a se submeter cegamente ao poder e à autoridade (Horkheimer, I950, p. IX).

Nesse âmbito, a noção de padrão ideológico pessoal se tornou primordial para a análise do autoritarismo, concepção tão importante para avaliarmos o cinismo do tipo antropológico aqui descrito. Este padrão seria designado como uma resolução de compromisso entre as necessidades específicas de cada personalidade que seriam, entáo, satisfeitas mediante interação com conteúdos ideológicos culturalmente disponíveis. Tal padrão, sendo particularmente individual, não se confunde com o conceito de ideo$\operatorname{logia}^{2}$, pois os conteúdos ideológicos circulantes na cultura seriam mobilizados individualmente enquanto objetos de satisfação pulsional de autoconservação ou agressividade, conforme as peculiaridades e necessidades mais ou menos conscientes em cada um. O padrão ideológico pessoal, que satisfaz necessidades psíquicas e emocionais, apresenta-se como uma estrutura estável, mesmo que seus conteúdos sejam internamente contraditórios: este padrão "se realiza em múltiplas combinaçôes cuja 'coerência' não pode ser dada de forma antecipada - uma questão que o inconsciente freudiano já havia indicado há muito tempo" (Antunes, 20I4, p. I50). Ou, de forma mais completa:

O que o indivíduo constantemente diz em público, o que diz quando se sente seguro de críticas, o que pensa mas não diz nada sobre, o que pensa mas não admite a si mesmo, o que ele está disposto a pensar ou a fazer quando vários tipos de apelos são feitos a ele - todos esses fenômenos podem ser concebidos como constituindo uma estrutura única. A estrutura pode não ser integrada, pode conter contradiçóes, bem como consistências, mas é organizada no sentido segundo o qual suas partes constituintes estão relacionadas de formas psicologicamente significativas (Adorno, Frenkel-Brunsivik, Levinson, Sanford, I950a, p. 5).

2 "As ideologias têm uma existência independente de qualquer indivíduo; e aquelas que existem em um momento particular são resultados de processos históricos e de eventos sociais contemporâneos. Essas ideologias têm, para diferentes indivíduos, diferentes graus de apelo, uma questáo que depende das necessidades individuais e do grau em que essas necessidades estão sendo satisfeitas ou frustradas" (Adorno, Frenkel-Brunsivik, Levinson, Sanford, I950a, p. 2). 
Assim, as diferentes expressóes de desejos como satisfaçóes de pulsôes seriam em níveis mais ou menos conscientes, constituindo um todo unido, mesmo que contraditório. Como exemplo, podemos pensar que um desejo inconsciente de segurança estaria relacionado a um sentimento íntimo de pavor, distância e menosprezo contra determinada minoria que supostamente ofereceria perigo, expressão esta que só seria aceita por si mesmo e por outros por meio de opiniôes formuladas mediante racionalizaçóes socialmente aprovadas e difundidas que "mascarariam" o autoritarismo. Opinióes que, quando racionalmente analisadas, mostrar-se-iam frágeis e controversas. Como veremos mais à frente, esta contradição psíquica seria um reflexo da própria contradiçáo social: em uma democracia que aceita a circulação de concepçóes autoritárias na cultura, os valores democráticos são tomados como somente formais, ao passo que os conteúdos preconceituosos seriam mobilizados para expressar o que o indivíduo realmente pensa.

Sua ideologia "oficial" se conforma com o que ele supõe que tem que pensar; suas "ideias reais" são uma expressão de suas necessidades pessoais mais imediatas, bem como de seus impulsos [urges] psicológicos. A ideologia "oficial" pertence à esfera objetivada e alienada do político, a "opinião real", à própria esfera do sujeito, e a contradição entre os dois expressa sua irreconciliabilidade (Adorno, I950a, p. 67I).

Visto isso, a pesquisa empírica de TAP procurou desvendar o máximo possível do padrão ideológico dos entrevistados por meio de testes projetivos e perguntas indiretas: caso fosse questionado diretamente sobre preconceitos, o autoritário iria negar veementemente.

É necessário frisarmos o uso das racionalizaçôes: elas seriam entendidas como deslocamentos de sentido ou até mesmo desvios de posicionamentos agressivos (que seriam "tabu" se abertamente ditos) realizados como manifestaçôes feitas "em um modo 'tolerável', modificado, indireto, em conformidade com os requisitos sociais que o eu está pronto a aceitar" (ibid., pp. 675-676). Sendo a base da própria possibilidade de expressão do mais autoritário, as opiniôes aparentemente inofensivas de cunho pseudodemocrático seriam, no fundo, uma reação pulsional agressiva disfarçada ou desviada. Adorno define, em poucas palavras, que "As racionalizaçóes são cicatrizes da razão em seu estado de irracionalidade" (Adorno, 2004, p. 59).

Inclusive, nem a oposição dos discursos proferidos pelo autoritário em contradição com as próprias vivências seriam suficientes para desfazer ou até mesmo questionar o padrão ideológico pessoal. Por isso, o que encontramos na obra seria a expressáo de uma racionalidade irracional em confronto ou afastamento relativamente à própria experiência. Uma vez que o indivíduo apenas reproduziria conteúdos socialmente massificados determinados segundo a necessidade psíquica sem que experiências possam abalar seu padrão ideológico estruturalmente estabelecido, então, percebemos como não seria realizada qualquer reflexão sobre a validade e pertinência dos discursos preconceituosos e autoritários proferidos como meras opinióes. Eis a forma esclarecedora como Adorno descreve a resoluçáo da contraposição de opinióes estereotipadas assumidas pelo indivíduo em conflito ou afastamento com a experiência: 
A discrepância entre experiência e estereótipo é colocada a serviço da atitude preconceituosa. O sujeito preconceituoso é vagamente consciente de que o conteúdo do estereótipo é imaginário e que sua própria experiência representa a verdade. No entanto, por razóes psicológicas mais profundas, ele quer se ater ao estereótipo. Isso ele alcança transformando este último em uma expressão de sua personalidade e os elementos anti-estereotipados, em uma obrigação abstrata. Esse deslocamento é reforçado por sua convicção mais íntima de que os supostos estereótipos de tolerância não são tấo fortes socialmente como ele finge que são. Ele percebe que, embora ele pareça se rebelar contra os slogans da democracia e da igualdade, por razóes que lhe são estritamente pessoais, ele é realmente apoiado por poderosas tendências sociais. Contudo, ele alegará, ao mesmo tempo, que age como uma pessoa sincera e independente que não se importa com o que os outros pensam. Além disso, ele confia na ideia de que seus próprios sentimentos são sempre mais fortes do que as convençóes, que ele simplesmente tem de segui-los e que seu preconceito é uma espécie de fatalidade que não pode ser mudada (Adorno, I95ob, pp. 627-628).

A descrição acima feita em TAP por Adorno designa uma das principais características $^{3}$ do tipo autoritário: o cinismo. Por mais que os autores não tenham fornecido uma definiçáa bem delineada deste conceito, o cinismo é empregado com frequência na obra quando relacionado a racionalizaçóes emitidas de maneira fria e apática como justificativa para agressividades. É frequente a existência de contradições na emissão de discursos cínicos: por exemplo, como a recusa de todo tipo de violência de forma abstrata e geral paralelamente à defesa de uma necessidade quase inevitável de violência quando relacionada a determinados grupos e situaçóes (Safatle, 2008, p. 77).

O cinismo é entendido aqui como a duplicidade mais ou menos consciente de discursos contraditórios racionalizados — que "mascarariam" satisfaçóes de pulsôes agressivas - encontrados no mesmo padrão ideológico pessoal. As contradiçôes seriam, então, organizadas de forma psicologicamente significativa. O cinismo só seria possível dado o distanciamento entre os discursos ideológicos selecionados segundo necessidades pulsionais individuais e a própria experiência vivida pelos sujeitos. De forma que faltaria ao cínico o acesso significativo a um campo empírico que legitimasse, em um conjunto de afirmaçóes contraditórias, o que se colocaria como objetivo, verdadeiro e moral.

\section{0 modelo fetichista de cisão do eu}

Nesta análise psicanalítica do tipo antropológico autoritário em sua especificidade cínica, iremos nos remeter principalmente ao que Freud designou por cisão [Spaltung] do eu a fim de compreendermos como é possível duplicidades simultâneas quando em referência a um mesmo objeto. Mediante um mecanismo de defesa concebido como uma clivagem

3 As características da personalidade de tipo autoritário estão expostas nas variáveis da famosa Escala F, descritas como sintomas que formam uma síndrome. Eis a lista das características principais: convencionalismo, submissão acrítica a autoridades, agressão autoritária, anti-intracepção, superstição e estereotipia, toughness, destrutividade e cinismo, projeçóes, preocupação exagerada em relação ao sexo. 
no interior da instância responsável pela própria síntese psíquica, talvez compreendamos melhor a condição de um tipo antropológico dotado de uma racionalidade irracional, sujeito esclarecido e supersticioso. Nesse sentido, Freud nos lembra como o fetichismo é um objeto particularmente favorável para o estudo da cisão do eu (Freud, I99Ia). No entanto, é de primeira necessidade levantarmos antes algumas ressalvas que apontam para o uso específico da homologia entre o cinismo e o fetichismo que propomos aqui fazer.

É frisado várias vezes ao longo de TAP que o tipo de personalidade autoritária, apesar de considerada "normalizada" ou "bem ajustada" na sociedade, apresentaria sintomas. Neste sentido, o abandono dos parâmetros da realidade na emissão de opinióes que guiam açóes e interaçóes sociais seria a característica principal do sintoma do tipo autoritário, de modo que sua relativa padronização em numerosos indivíduos levaria a "uma 'síndrome', embora as variações típicas dentro deste grande padrão possam ser distinguidas" (Adorno, Frenkel-Brunsivik, Levinson, Sanford, I950a, p. I). Nesse sentido, para os autores de TAP, tal como um sintoma, o preconceito exerceria uma função de defesa ou de satisfação indireta de desejos na economia psíquica. Isso porque ele seria concebido como uma resolução de compromisso entre a satisfação das pulsóes agressivas e a necessidade de um comportamento voltado à sociabilidade (por meio das racionalizaçóes socialmente aceitas e estereótipos já fornecidos pela cultura).

Nesse sentido, estaria em jogo um tipo de patologia que versaria sobre o social não só porque os autores tratariam de um sintoma em um tipo antropológico, mas também porque tais estereótipos e racionalizaçóes seriam provenientes de ideologias circulantes na cultura, sendo estas objetivamente identificáveis. Logo, a gênese do comportamento parcialmente irracional da racionalidade do tipo autoritário seria encontrada em aspectos da sociedade que condicionariam a constituiçáo subjetiva de um grupo identificável de seres humanos determinados por um contexto específico. Sob tal perspectiva, a crítica da normatividade social de um dado tempo e espaço poderia se converter em uma análise da produção social de sintomas típicos vividos individualmente. É desta forma que a antropologia freudiana, que se encontra na base de explicação do tipo autoritário, seria empregada na obra como instrumento de crítica social ao revelar certas condiçóes gerais e históricas de formação subjetiva.

Tal "síndrome" como padronização de sintomas de um tipo antropológico, contudo, não aproximaria os preconceituosos da neurose, muito menos da psicose. Eis as palavras de Adorno sobre a interpretação de tais sintomas:

Nossa discussão anterior mostrou o aspecto irracional das atitudes e opinióes antissemitas. Uma vez que seu conteúdo é irreconciliável com a realidade, certamente temos o direito de chamá-los de sintomas. Mas são sintomas que dificilmente podem ser explicados pelos mecanismos da neurose; e, ao mesmo tempo, o indivíduo antissemita como tal, o caráter potencialmente fascista, certamente não é um psicótico. A explicação teórica final de um sintoma inteiramente irracional, que, no entanto, não parece afetar a "normalidade" daqueles que apresentam o sintoma, está além do escopo da presente pesquisa (Adorno, 195ob, pp. 6I7-6I8). 
A relação entre patologia social e patologia individual em sentido clínico se dá por homologia entre a característica marcante do cinismo no tipo antropológico autoritário e o fetichismo segundo explanação freudiana. ${ }^{4}$ Tal homologia, no entanto, não seria uma mera comparação geral de semelhança por analogia. A homologia a que nos referimos revela uma mesma lógica de estruturação e funcionamento. Afinal, desde Freud sabemos que psicopatologias são descritas para além do comportamento estritamente sexual, definindo uma organização psíquica que engloba modos de estabelecimento de estruturas pulsionais e simbólicas que permitirão a sujeitos atuarem socialmente por meio de uma singular constituição emocional, pulsional e racional, além de certo conjunto de fantasias que ajudarão a delimitar a própria identidade e as interaçôes com alteridade. Contudo, guardemos que a homologia do cinismo com o fetichismo, tal qual definido por Freud, não faz do primeiro uma patologia em si, muito menos faz do cínico um fetichista.

O fundamento de tal homologia encontra-se na noção de cisão do eu como base genética da constituição de uma estrutura fetichista. Segundo Freud, a construção do fetiche ocorreria mediante uma defesa contra o trauma da ausência do pênis na mulher na fase do complexo de castração, momento em que a revelação da diferença entre si mesmo e o outro se coloca de modo operante para a psique humana. A fim de evitar um conflito psíquico referente à possibilidade da castração, o fetichista aceitaria o dado perceptivo de ausência de pênis na mulher, ao mesmo tempo em que também manteria a crença no falo feminino. Essa duplicidade contraditória seria possível pela cisão no interior da instância egoica que permitiria, então, a formação do objeto fetiche que, por substituição simbólica ou descentramento de valor, seria associado ao pênis feminino. Isso permite ao fetichista manter a crença no pênis da mulher por meio da adoração de um objeto fetiche, ao mesmo tempo em que aceita a representação objetivamente válida da mulher sem pênis, reconhecendo a diferença sexual. Ou seja, o fetichista não modificaria completamente os dados recebidos da realidade, mas os transformaria de forma apenas parcial - modo de manter simultaneamente em funcionamento o princípio do prazer e o princípio de realidade. Nas palavras de Freud, o que subsiste como a base da constituição do objeto fetiche

É uma formação de compromisso com ajuda de um deslocamento [...]. A criação do fetiche obedeceu ao propósito de destruir a prova da possibilidade da castração, de sorte que se pôde escapar da angústia de castração. [...] Por um lado, desmentem o fato de sua percepção, a saber, que nos genitais femininos não se viu pênis algum; por outro, reconhecem a falta do pênis da mulher e daí extraem as conclusões corretas. As duas atitudes subsistem uma junto da outra durante

4 Tal homologia entre cinismo e fetichismo ganha força no contexto em que teóricos da cultura e da psicanálise têm delimitado a substituição da noção de neurose pela perversão como psicopatologia relacionada à situação cultural e econômica mais recente. Como exemplo, Jean Lebrun fala de neo-sujeitos que partilham de uma economia psíquica coletiva perversa, mas de forma ordinária, não estrutural (Lebrun, 2007, p. 42). Nesse mesmo sentido, Safatle segue Lacan ao identificar a père-version como o funcionamento privilegiado de identificação com a lei paterna no capitalismo contemporâneo (Safatle, 2008, p. 22). 
toda a vida sem se influenciarem reciprocamente. É o que se tem direito de chamar uma cisáo do eu. Estes estados de coisas nos permitem compreender também que com tanta frequência o fetichismo alcance só uma modelação parcial. Não governa a eleição de objeto de uma maneira excludente, senáo que deixa espaço para uma extensão maior ou menor de conduta sexual normal, e ainda muitas vezes se retira a um papel modesto ou à condição de mero indício. Portanto, os fetichistas nunca alcançaram o completo desprendimento do eu em relação à realidade objetiva do mundo exterior (Freud, I991a, pp. 204-205).

\section{Modelo fetichista versus modelo paranoico}

A leitura aqui recuperada diverge de algumas pesquisas clássicas sobre o antissemitismo - como as de Santner, Canetti, Simmel, entre outros - que priorizam o modelo da paranoia. Inclusive a associação do fascismo com a paranoia é uma das bases teóricas do imprescindível capítulo "Elementos de Antissemitismo" presente em Dialética do Esclarecimento (Dialektik der Aufklärung ou DdA daqui em diante) de Horkheimer e Adorno. Dentre as muitas passagens que abordam essa associação, lemos:

O realismo incondicional da humanidade, que culmina no fascismo, é um caso especial do delírio paranoico, que despovoa a natureza e, ao fim e ao cabo, os próprios povos. É nesse abismo de incerteza, que todo ato objetivador tem que atravessar, que se aninha a paranoia. Como não há nenhum argumento absolutamente convincente contra os juízos materialmente falsos, não é possível curar a percepção distorcida em que eles surgem (Horkheimer e Adorno, 1985, p. 159).

Chama a atenção que ambos os estudos tenham sido feitos na mesma época - TAP foi escrito desde I944 e publicado em I950 e DdA foi escrito em I944 e publicado em 1947 - e que tenham envolvido, para além dos pesquisadores de Berkeley, também Adorno e Horkheimer. Visto isso, como conciliar a nossa leitura sobre o fetichismo em TAP com as assertivas sobre a paranoia em DdA? Para tanto, apresentemos as aproximaçóes e afastamentos da gênese e funcionamento de ambas as psicopatologias em relação ao preconceito de forma geral e, particularmente, ao cinismo.

Em relaçáo ao preconceito em geral, a paranoia seria o modelo privilegiado para pensarmos a dose de agressão e destrutividade envolvidas na interação social, construída de forma dicotômica, com minorias. De modo mais específico, a própria divisão da sociedade e classificação de pessoas, como por exemplo "de bem" e "bandido", "amigo" e "inimigo", carregariam marcas tipicamente paranoicas. Seria característica da defesa paranoica a separação de interaçôes humanas e simbolizaçóes sociais em categoriais quase espaciais de interior e exterior, eu e não-eu, como forma de manter o rígido sistema explicativo que sustenta seus delírios. Rigidez que impossibilita o questionamento subjetivo sobre a veracidade de suas próprias afirmações. Em tal perturbação epistemológica, o paranoico apelaria, então, ao "vício da causalidade" para justificar suas torçóes na percepção da realidade: um problema subjetivo seria projetado na alteridade, tornando-se culpa do perseguidor ou da minoria — tidos como bodes expiatórios. Ao não se rela- 
cionar a nada que não faça referência a si, o paranoico em sua característica narcísica não reconheceria a alteridade por ela mesma, não compreendendo os acontecimentos da ordem social como minimamente separados de si.

Entretanto, é em um quesito aparentemente comum entre fetichismo e psicose que encontraremos ao menos três pontos centrais de afastamento do tipo autoritário cínico em relação ao modelo paranoico. Percebamos que a semelhança principal entre a formação da psicose - categoria clínica mais geral que engloba a paranoia como uma de suas representantes específicas - e do fetichismo seria que ambos os processos seriam constituídos mediante o mesmo mecanismo de defesa, a Verleugnung, que traduzimos aqui por desmentido. Apresentemos as diferenças etiológicas segundo as reaçóes ao complexo de castração. No caso neurótico ocorreria a repressão do afeto relacionado à angústia da mulher sem pênis e a aceitação e internalização desta informação apreendida do exterior. A situação conflituosa seria, então, transferida para o interior da estrutura psíquica do neurótico. Já no psicótico e fetichista, o desmentido atuaria negativamente sobre a representação da falta do pênis na mulher. Especificamente no caso da paranoia, tal informação não seria internalizada, mas re-transferida integralmente para a objetividade. Nesse âmbito, a própria realidade precisaria sofrer modificaçôes para se adequar ao conteúdo que fora negado no sujeito e projetado para fora. Daí a noçáo de delírio. No caso fetichista, o dado da falta do falo da mulher teria sido simultaneamente internalizado e também transferido para uma representação substituta, criando o fetiche que manteria viva a fixação no pênis feminino. Por isso, o fetichista não precisaria modificar nada na realidade, pois se conformaria com a determinação social da divisão dos sexos, informação que fora internalizada, mas manteria, de forma privada, a sua crença ou fantasia.

Considerando a diferenciaçáo da atuaçáo do desmentido em ambas as psicopatologias, um primeiro afastamento da paranoia em relação ao cinismo se mostra presente: como vimos ao abordarmos as racionalizaçóes, o tipo antropológico de TAP também se caracterizaria pelo convencionalismo, isto é, pela adequação a ideologias socialmen-

5 Outro ponto relativo à cisão psíquica pode ser ainda levantado. Freud nos alerta que haveria casos de cisão do eu considerados normais ou não-patológicos, uma vez que a cisão constituiria uma possível defesa infantil contra representaçóes do mundo exterior sentidas como dolorosas. Esta é a forma na qual crianças desenvolveriam as primeiras teorias sexuais - como por exemplo, a teoria de que o pênis feminino ainda está pequeno e irá crescer (Freud, I992c, p. I47) — a fim de contrariar a percepção. No curso "normal" de desenvolvimento infantil, no entanto, a criança posteriormente desativaria a denegaçáo ligada à cisão do eu, assumiria plenamente a realidade da ausência do pênis feminino e passaria, portanto, ao recalque [Verdrängung] tipicamente neurótico. Caso a manutenção do desmentido permanecesse para além da infância, seria constituído um caso de fetiche (se a negação do dado externo for parcial) ou ainda de psicose (se a negação da realidade for total). Considerando a cisão do eu sob tal viés, o cinismo do autoritário poderia ser entendido como um tipo de raciocínio infantil, próprio da "menoridade" humana. A continuidade de tal linha de argumentaçáo pode nos levar a uma melhor compreensão da distinção entre normalidade e patologia do tipo autoritário: "le néo-sujet pratique le démenti pour éviter la subjectivation, alors que le vrai pervers fait du démenti son mode même de subjectivation, lequel lui permet d'annihiler l'altérité de l'autre en l'instrumentant" (Lebrun, 2007, p. 327). 
te produzidas e difundidas, adequação que o sistema paranoico não poderia admitir. Isso porque um "ajuste" em favor da convenção social poderia ameaçar o já frágil "sistema delirante" paranoico a ponto de ruir toda a sua construção. Logo, a resposta psicótica seria considerada excessivamente individual, como uma totalidade pessoal. Claro que, no interior do delírio paranoico, figuras sociais poderiam assumir papéis de liderança em uma aproximação com autoridade sociais, políticas ou religiosas, mas o posicionamento privilegiado de tais figuras na organização psíquica ocorreria devido exclusivamente às peculiaridades do sistema psíquico subjetivo. De forma mais direta, na paranoia os dados sociais se adequariam ao sistema individual, ao passo que, no tipo autoritário, seria principalmente o sujeito que se adequaria ao sistema social. Assim, se a própria definição freudiana faz da psicose "o desenlace [...] de uma [...] perturbação nos vínculos entre o eu e o mundo exterior" (Freud, I992e, p. I55), podemos dizer que a adequação às convençóes sociais e ideologias dominantes por parte do tipo autoritário o deixaria mais próximo do fetichista, para quem tal adequaçáo existe, mesmo que parcialmente. Esta substituição de um modelo paranoico para um outro mais "racional", porque voltado, ao menos parcialmente, para a realidade externa é defendida pelo próprio Adorno em The psychological techniques of Martin Luther Thomas' radio addresses, texto também contemporâneo a TAP em que o filósofo analisa os programas de rádio onde Thomas veiculava um discurso fascista:

Thomas fornece uma boa consciência intelectual para aqueles que não conseguem pensar. Ele astuciosamente substitui um esquema "paranoico" por um processo racional. O dispositivo mais importante de sua lógica de manipulação é sua técnica de transiçóes associativas (Adorno, 2000, pp. 33-34).

O apelo a um processo racional baseado na técnica de transiçóes associativas de ideias "reificadas", isto é, que já aparecem prontas e que são somente reproduzidas pelos indivíduos não seria, então, possível de ser feita em um sistema paranoico. A própria substituiçáo de objetos (ou discursos “objetificados") que seriam mais adequados, ao menos momentaneamente, à satisfação de desejos é algo que encontramos no funcionamento fetichista.

Um segundo momento em que o modelo paranoico se torna dispensável à análise do tipo autoritário é na defesa de seu sistema delirante, quando o paranoico transforma seu corpo em um símbolo de onipotência que, como tal, não poderia permitir cisóes internas, passividade ou quaisquer sinais que o aproximassem de uma possível vulnerabilidade. Assim, uma cisão do eu e uma decorrente posição cínica seriam impossíveis de serem sustentadas em um modelo paranoico de funcionamento psíquico. O tipo autoritário, sendo cínico, sabe da precariedade, incompletude ou falha tanto da sua submissão ao convencionalismo social, quanto de seu subterfúgio prazeroso designado como objeto fetiche. Contudo, seria justamente mediante tal incompletude mesma que seu posicionamento poderia ser conservado, permitindo a duplicidade paradoxal de suas afirmaçóes. 
Um último elemento de comparação entre o modelo paranoico e o fetichista se encontra na projeção e no narcisismo. Características importantes tanto para a paranoia quanto para o preconceituoso, elas não são, contudo, exclusivas de tal formaçáo psicótica. Isso quer dizer que a negação interna de representaçôes, que seriam projetadas na alteridade formando uma realidade interna sem conflitos (ou narcísica), estaria mais relacionada justamente ao próprio desmentido em si, sendo possível de ser encontrado também no fetichismo. Uma vez que o fetichista também projetaria na alteridade aquilo que abala sua estrutura narcísica, ele ainda o faria de forma incompleta, deixando um resíduo denominado fetiche. Quanto a isso, lembremos que Adorno et al. definem o afastamento da experiência do totalitário como um sintoma. Ora, o desmentido do paranoico não poderia ocasionar a formaçáo de sintoma, já que o delírio psicótico tomaria o eu de forma completa, o que afastaria a definição de delírio (e aproximaria a concepção de fetiche) da noção de sintoma como substituto da representação da satisfação pulsional negada.

A distância entre o modelo fetichista e o paranoico nas análises do preconceito em TAP e DdA residiria principalmente no contexto considerado como base de análise das obras. Não esqueçamos que a abordagem paranoica de "Elementos de Antissemitismo" foi abundantemente analisada tendo em vista o fascismo, mais precisamente o momento abertamente totalitarista do Terceiro Reich alemáo. A violência direta, ou seja, dotada de menos racionalizaçóes e realizada conforme um programa de extermínio em massa de um grupo étnico como "soluçáo final" parece necessitar de um sistema estruturado em uma totalidade quase delirante de justificativa, em que questionamentos, paradoxos ou dubiedades náo seriam admitidos. Acreditamos, no entanto, que uma pesquisa realizada nos Estados Unidos nos anos 1940, momento em que o país seguia um sistema político democrático menos abertamente autoritário, precisa ao menos da aparência formal de uma pretensão à igualdade humana. Assim, as experiências preconceituosas precisariam ser mais veladas, simbólicas, indiretas e racionalizadas para que a dominação e o extermínio de minorias possam ser levados a cabo. Nesse âmbito, é a manutenção do preconceito, autoritarismo e fascismo em contextos democráticos que nos leva ao interesse especial pelo cinismo, cisão do eu, desmentido e racionalizaçôes, culminando em uma homologia com o modelo fetichista.

O sintoma autoritário do distanciamento em relação à realidade deve também ser descrito relativamente à escolha de objeto de ódio, em homologia ao fetichista que nunca encontra uma satisfação pulsional em objetos empíricos, mas em objetos substitutos. Como sabemos, o autoritário precisa de um objeto substituto para satisfazer suas pulsôes, objeto este que também seria idealizado, como um símbolo quase onipotente que o permitiria fugir de determinado aspecto desprazeroso da realidade ou de si mesmo. A sua racionalidade repetiria exaustivamente o que Adorno chama de um termo autoritário fetiche.

O meio mais característico de propagandisticamente estabelecer autoridade de um modo quase racional, sem recorrer a instituiçóes tradicionalmente aceitas, consiste em tomar um termo autoritário e torná-lo uma espécie de fetiche. 
Este dispositivo foi observado pelo Dr. A. Sanders sob o título de "palavras mágicas". O melhor exemplo para este dispositivo é a personificação de regimes totalitários em todo lugar, por um Duce, um Führer ou [...] um líder (Adorno, 200o, pp. 38-39).

Antes de tudo, podemos notar que o objeto fetiche pode ser uma ideia ou termo, concebidos como "palavra mágica". Relacionando parcialmente o fetiche freudiano com o marxiano, podemos dizer que a repetição do objeto faz parecer que ele tem vida própria e independente, dotado de autonomia, portando-se como um fait accompli, isto é, como algo dado, sem gênese, nem explicação, nem história. Contudo, no fundo, esse objeto serviria para encobrir um outro conteúdo ou relação a ser negado. O mesmo ocorreria com uma ideia ou até mesmo um nome: estes não precisarão de uma justificativa ou gênese explicativa, sua mera repetiçâo se encarrega de torná-la fetichizada e encobridora. Resta saber, com isso, quais seriam tais ideias e até mesmo nomes fetichizados. Inferimos, pela citação acima, que um dos nomes ou ideias-fetiche mais evidentes do autoritário seria, evidentemente, a figura do líder.

Outro elemento que também pode ser considerado como o objeto fetiche do autoritário seria aquela designação insistentemente repetida para se referir ao inimigo, que se forma como objeto de ódio. Assim, propomos que, diferentemente do que aconteceria com o fetichista, uma das escolhas de objeto privilegiado do autoritário náo seria somente relacionada às pulsôes sexuais na sua ânsia de prazer, mas também obedeceria às pulsôes agressivas em sua forma indireta, defensiva, desviada. Com isso, seria possível a construção de um objeto dito "negativo", como exposto por Adorno em Teoria freudiana e modelo fascista de propaganda ao recorrer à leitura de Psicologia das massas e análise do eu:

Considerando que a libido positiva é totalmente investida na figura do pai primitivo, o líder; e que são poucos os conteúdos positivos disponíveis, é preciso descobrir uma negativa. "O líder ou a ideia dominante poderiam também, por assim dizer, ser negativos; o ódio contra uma determinada pessoa ou instituição poderia funcionar exatamente da mesma maneira unificadora e evocar o mesmo tipo de laços emocionais que a ligação positiva". Parece desnecessário dizer que essa integraçáo negativa se alimenta do instinto de destrutividade, uma figura que o pensador não refere explicitamente em Psicologia de massa, mas cujo papel decisivo ele todavia reconheceu em O Mal-estar na civilização (Adorno, I95I, p. 6).

\section{Análise metapsicológica do tipo autoritário em sua característica cínica}

A análise metapsicológica do tipo autoritário é feita em TAP mediante duas grandes assertivas: a formulação de um eu fraco e de um superego externalizado:

É uma função do eu fazer as pazes com a consciência, criar uma síntese maior dentro da qual a consciência, os impulsos emocionais e o self operam em relativa harmonia. Quando esta síntese não é alcançada, o superego ganha o papel de um corpo estranho dentro da personalidade e exibe os aspectos rígidos, auto- 
máticos e instáveis discutidos acima. Há alguma razão para acreditar que uma falha na internalização do superego se deve à fraqueza do eu, a sua incapacidade de realizar a síntese necessária, isto é, de integrar o superego consigo mesmo. Seja ou não assim, a fraqueza do eu parece ser concomitante ao convencionalismo e ao autoritarismo. A fraqueza no eu é expressa na incapacidade de construir um conjunto consistente e duradouro de valores morais dentro da personalidade; e é esse estado de coisas, aparentemente, que torna necessário que o indivíduo procure alguma organização e um agente [agency] de coordenação fora de si mesmo (Adorno, Frenkel-Brunsivik, Levinson, Sanford, 1950b, p. 234).

Comecemos pela questão da fragilidade do eu: na visão dos autores, o eu do tipo autoritário náo conseguiria sintetizar de forma equilibrada no interior de si os diferentes conteúdos provenientes da realidade externa, do superego e do isso. Assim, a cisão do eu seria considerada uma fraqueza na constituição psíquica do preconceituoso. Isso porque uma síntese psíquica poderia evitar um distanciamento em relação à realidade, o que livraria o autoritário de seu sintoma. Por outro lado, talvez por tal fragilidade, o eu náo conseguiria distanciar sua racionalidade de gratificaçóes prazerosas do isso, apresentando uma racionalidade vinculada à irracionalidade das racionalizaçóes subservientes a necessidades pulsionais defensivas, agressivas e também prazerosas.

Como segundo ponto, a instância do superego, em sua formulação considerada por Freud, seria justamente o resultado da síntese entre o isso e os conteúdos da realidade externa: o "superego [...] reúne em si influxos do isso tanto quanto do mundo exterior e é, por assim dizer, um arquétipo ideal daquilo que é a meta de todo querer alcançar do eu: a reconciliação entre suas múltiplas vassalagens" (Freud, I992e, p. 157). Sob tal ponto de vista, uma fraqueza na síntese do eu levaria inevitavelmente a um problema na formação do superego, este sendo o resultado, ele mesmo, de uma síntese. O superego figura, então, como o saldo da situação edípica ao se constituir por meio da internalização das figuras de autoridade parentais e sociais.

Visto isso, passemos à descrição da estrutura familiar do tipo autoritário. TAP expóe que os mais preconceituosos praticariam uma superestimação irreal dos progenitores segundo noçóes estereotipadas, o que sugeriria que a educação infantil fornecida pela família tenderia à rigidez, disciplina estrita e distância, na qual uma relação familiar mais igualitária e segura teria sido impossibilitada. Logo, para eles, a figura de autoridade tenderia a ser considerada poderosa, amedrontadora e dominadora, frente à qual o indivíduo em formação só poderia se subjugar. Em tal relação hierárquica rígida, a submissão infantil a regras familiares ocorreria prioritariamente por medo, mais do que por compreensão racional destas imposiçóes. Com isso, a relação familiar ficaria marcada por noçóes de obrigação e dever, e náo por sentimentos ternos e sinceros.

Para os autores, a consequência disso para a formação subjetiva seria, primeiramente, a artificialidade da noção das regras, que não teriam sido compreendidas em seu conteúdo, mas seriam acatadas somente pelo formato da lei. Pode-se dizer que, uma vez impossibilitado de desenvolver uma crítica saudável à autoridade, o eu não teria 
podido se formar de modo a integrar completamente o superego às demais instâncias psíquicas - o que leva à constituição de um superego externalizado. Uma vez que o sujeito só aceitaria a forma abstrata da lei, mas náo teve os valores e conteúdos morais compreendidos de modo suficiente, o lugar onde seriam formulados julgamentos sobre a justiça, bondade e respeito a ações e situaçôes sociais seria feito em um domínio externo ao tipo autoritário. Seria perdida, então, a capacidade crítica quanto à reflexão e questionamento das leis sociais. A tendência é que o preconceituoso somente acate e reproduza o conteúdo moral socialmente dominante. Por consequência, nenhuma culpa seria produzida internamente ao tipo autoritário, pois não ocorreria uma análise da violação ou não de normas mais ou menos justas socialmente, não havendo julgamento e responsabilização interna pelas condiçóes sociais.

Ademais, dada a sua internalização incompleta, as funções superegoicas dos mais preconceituosos podem ser projetadas em uma figura social, líder ou autoridade. Tal pessoa seria escolhida pela associação com as características do pai: produzindo medo e intimidação, enfatizaria a puniçáo e condenaçáo excessivas inclusive para os menores desvios, pregaria a exclusão ou segregação de determinados grupos das camadas sociais mais frágeis, reforçaria o status quo econômico-social e culturalmente já dominante, prometeria bens materiais como recompensas morais, em suma, basearia seus argumentos não em conclusóes racionais, mas em manipulação de medo, desejos e agressividade. Assim, sendo a sua formação egoica frágil, o tipo autoritário tentaria procurar na figura do líder e na conformação social a organização ordenadora e moralizante que faltaria em seu interior: "O que o fascista participante procura é a ilusão de controle em ordem de reparar sua sensação de impotência” (Benjamin, I977, p. 55).

Tal explicação encontrada em TAP nos permite dizer que as funções próprias de instâncias subjetivas como que se "expandem" para o exterior, criando uma espécie de noção alargada de eu e de superego que operariam em nível social. Algo bem próximo da explicação fornecida por Freud em Psicologia das massas e análise do eu onde compreendemos que a formação de uma massa narcísica ocorreria por projeção da estrutura idealizada de si mesmo na figura do líder. Por outro lado, podemos pensar que se o viés idealizado do superego seria transferido para uma figura externa, o eu — que deveria sofrer com as represálias de um superego interno - também se encontraria associado às figuras ditas mais frágeis da sociedade. Como alerta Sanford,

Devemos entender, no entanto, que no cinismo a destrutividade é dirigida contra o eu, bem como contra o mundo. Não é só que a própria agressividade do sujeito é projetada sobre outras pessoas, que são entáo acusadas de serem gananciosas e belicosas, mas o desprezo por outras pessoas parece estar intimamente relacionado com o desprezo por si mesmo. No caso de Mack - e isso provavelmente é válido para personalidades autoritárias —, o autodesprezo deriva de sua sensação de fraqueza e isso, como vimos, é o resultado de sua rendição a seu pai. Esta rendição não pode ser totalmente desculpada, e enquanto ele não puder se permitir se sentir agressivo para com aqueles que sáo realmente fortes, haverá um irritante lembrete de que ele, na realidade, é fraco (Sanford, 1950, p. 806). 
Para evitar um conflito interno entre instâncias psíquicas, tal embate seria transferido para o nível social, gerando admiração a certos líderes sociais e ódio aos grupos socialmente "frágeis".

Uma vez que a produção de pensamentos próprios necessitaria de uma síntese psíquica, e considerando que o eu apareceria fragilizado e o superego externalizado, podemos dizer que a produção de conteúdos ideológicos seria feita fora do sujeito. Mas é possível dizer ainda mais: ocorreria uma "dessublimação", isto é, a transformação de conteúdos outrora racionais em pulsionais que passariam, então, a ser instrumentalizados socialmente, diretamente manipulados para fins de controle social dos indivíduos. Se a sublimaçáo é caracterizada em Freud pelo desvio da finalidade pulsional na qual a agressividade não seria diretamente descarregada, mas desviada; então a dessublimação consiste na retomada das pulsôes agressivas anteriormente sublimadas, levando-as à sua meta primeira de descarga pulsional direta em violência real. Assim, não só o eu e o superego seriam "externalizados", mas o mesmo ocorreria com certos conteúdos inconscientes do isso, havendo uma “'dessublimação' de impulsos arcaicos e violentos do isso em movimentos fascistas; então deve ser válido dizer que a manipulação substituiu a internalização" (Benjamin, 1977, p. 56).

\section{Cinismo e complexidade}

Considerando que TAP segue o parâmetro metodológico da primeira geração da Teoria Crítica, lembramos como a individuação por socialização só poderia encontrar uma gênese da modificação de traços metapsicológicos no interior do contexto social. Para tanto, é necessário lembrar como conclusóes de trabalhos anteriores do Instituto continuam em vigor na análise de TAP. Principalmente a ideia de Horkheimer, vigente nas pesquisas empíricas do Instituto desde os anos 1930, segundo a qual teria havido a falência simbólica da autoridade paterna no âmbito familiar, consequência do avanço do capitalismo (Whitebook, 1995, p. 137).

É a partir de tal análise que posteriormente Adorno desenvolve a sua teoria segundo a qual não somente a família deixou de ser responsável pela mediação entre indivíduo e sociedade; além dessa premissa básica, Adorno passou a afirmar também que a mercadoria havia tomado o lugar da família nessa mediação: “a verdadeira 'mediação' entre psicologia e sociedade não se situa na família, mas na mercadoria e no fetiche, $o$ fetichismo é o verdadeiro correlato da reificação" (Ver Genel, 20I0, pp. 6-7).

Colocar a mercadoria no centro da formação humana na sociedade capitalista transfere a pauta principal de pesquisa para uma forma de submissão que envolve não só a produção industrial de conteúdos culturais, como também a recepção de tais conteúdos pelo indivíduo, o que modifica a sua relação com a experiência e realidade. Isso indica como os autores perceberam o avanço do capitalismo que se expandiu para todas as esferas sociais, inclusive para a família, culminando na mercantilização e objetificação de relaçóes humanas e do próprio pensamento.

Dito isso, é importante considerar a proximidade entre as ideologias, discursos e 
objetos-fetiche operados pela racionalidade do autoritário e a noção de mercadoria. Assim como as mercadorias no capitalismo aparecem no mercado como prontas, autônomas, aparentemente desvinculadas da ação e produção humanas, o mesmo ocorreria com as próprias ideologias, que circulam na indústria cultural como "objetificadas" ou "reificadas", já prontas para serem consumidas pelo indivíduo. As ideologias ou discursos autoritários objetificados se tornaram, então, objetos pulsionais de satisfação agressiva, sendo denominado por Adorno como objetos-fetiche ou "palavras mágicas".

O meio mais característico de estabelecer autoridade propagandisticamente de maneira quase racional, sem recorrer a instituiçôes tradicionalmente aceitas, consiste em tomar um termo autoritário e torná-lo uma espécie de fetiche. Este dispositivo foi apontado pelo Dr. A. Sanders sob o título de "palavras mágicas". [...]. É em si mesmo o resultado da sociedade industrial tardia, conforme ao menos pode ser sugerido. O intermediário entre a racionalidade industrial e a idolatria mágica é a publicidade. A técnica da competição desenvolveu certa tendência de transformar os slogans sob os quais as mercadorias são vendidas em mercadorias mágicas (Adorno, 2000, pp. 38; 40).

Sem uma mediação entre indivíduo e sociedade, anteriormente preenchida pela família, os indivíduos estariam sendo diretamente socializados por mecanismos mercadológicos presentes em discursos e ideologias circulantes na cultura. $\mathrm{Na}$ ausência de um momento intermediário que pudesse filtrar, analisar e questionar tais conteúdos, o indivíduo se comportaria somente como um mero receptor e reprodutor de ideologias tomadas como objetos-fetiche de satisfação pulsional.

Nesse contexto, lemos a falência da figura paterna como a situação em que a família teria se tornado somente reprodutora de um modus operandi mercadológico, seja na importância dada aos valores capitalistas como prestígio e escalonamento social, ou ainda como meio propagador da reificação e objetificação de pessoas e ideologias. Disso se segue que a compreensão da falência da autoridade familiar não significa exatamente a extinção de sua figura, mas sim o fim de um posicionamento de autoridade produzido por si só sem a influência direta de outros domínios que não familiar. Ou seja, a autoridade familiar deixa de se efetivar enquanto elemento constituinte da dialética histórico-social, tornando-se apenas um meio de afirmação da esfera econômica capitalista. O papel ativo da família na formação subjetiva e atuação social do indivíduo em formação teria sido paralisado, estancado sob a excessiva proximidade de determinaçóes sociais.

Quando se perde a distância entre indivíduo e sociedade, perde-se também a própria capacidade inventiva e crítica de reflexão e contraposição. $\mathrm{O}$ indivíduo se alienaria a tal ponto que se tornaria, ele mesmo, ideologia. Como atesta Adorno,

Se o conceito de homem, do que se trata, converteu-se em ideologia porque os homens se limitam a ser apêndices da maquinaria, poder-se-ia dizer, então, sem exagerar muito, que na situação presente seriam os homens mesmos, em seu ser-assim e não-de-outro-modo, literalmente, a ideologia que se dispóe a eternizar a vida falsa, apesar de sua manifesta absurdidade (Adorno, 2004, p. I8). 
Seguindo tal pensamento, podemos constatar uma modificação da noção de ideologia: uma vez expandida até se tornar quase total, a peculiaridade descritiva do termo teria se esvaziado em seu poder explicativo.

O conceito de cinismo torna ainda mais complexa a já problemática noção de ideologia: o tipo autoritário, em sua duplicidade constitutiva, reconheceria a insuficiência tanto das ideologias, quanto das próprias críticas a tais conteúdos. Não sendo um completo refém de pensamentos reificados, nem por isso o cínico agiria desmascarando ideologias, mas continuaria a segui-las de modo alienado, mesmo sabendo da inadequação de tais ideias. Os discursos circulantes na cultura lhe seriam transparentes em suas falsidades, mas isso não seria suficiente para anular o poder de reguladores práticos da própria vida e interaçóes sociais:

Ao afirmar que a diferença entre ideologia e realidade desapareceu, Adorno procura lembrar que, na contemporaneidade, a ideologia transparece e afirma-se enquanto tal na própria efetividade, sem que isso modifique o engajamento dos sujeitos em seu campo. Ele insiste na existência de certa relaçáo de duplicação [Verdoppelung] entre ideologia e realidade, a fim de lembrar que "a ideologia não é mais uma capa [Hülle], mas a ameaçadora aceitação [Antlitz] do mundo" (Safatle, 2008, p. 96).

Importante notar que o cinismo tornaria os discursos ideológicos táo dúbios em sua efetividade que nenhuma figura-fetiche poderia ser sustentada com convicção, pois, no fundo, ele poderia saber que tal líder ou minoria não era objeto tão adequado assim para as suas pulsóes - o que não o impossibilitaria de investir ódio e admiração neles. Daí a necessidade de sempre renovar os objetos de investimento quando as reservas em relação à adequação do discurso perante a realidade se tornassem excessivas. Uma vez que o modo de estruturação cínico do pensamento não seria desativado juntamente com a mera troca de tais objetos, podemos pensar que é a própria falibilidade desta operação que a permitiria continuar funcionando. Afinal, nunca se teria acreditado completamente em uma acusação ou em um líder, sendo possível sempre assumir o contrário do que fora anteriormente defendido. Daí também a necessidade de sustentar simultaneamente duas afirmaçóes opostas em relação ao mesmo conteúdo, pois o autoritário poderia mudar o seu posicionamento conforme lhe pareça mais conveniente. Modo homólogo de funcionamento do próprio fetiche, que se alimenta da fragilidade das escolhas de objetos que nunca passariam de simulacros ilegítimos, aparências que se reconheceriam enquanto tal, frutos de mera encenaçáo que, enquanto produtos de determinaçóes contraditórias, nunca poderiam se apresentar como empíricos.

Modo de não assumir posicionamentos críticos a fim de se manter apto a trabalhar e consumir, o cinismo autoritário encontraria na passividade uma forma de sobrevivência e perseverança em um mundo onde não se acham motivos suficientemente fortes para um rompimento com o sistema operante. A insatisfação de um posicionamento dual, que nunca poderia ser completamente realizado, precisa ser somente administrada, única forma minimamente racional de prosseguir com a assunção parcial de ideias e valores 
que não podem ser integralmente assumidos. $\mathrm{Ou}$, como diz de forma mais completa Sloterdijk:

Psicologicamente, os cínicos de hoje podem ser entendidos como melancólicos-limite que podem manter os seus sintomas de depressão sob controle e podem permanecer mais ou menos aptos a trabalhar. Na verdade, este é o ponto essencial no cinismo moderno: a habilidade de seus portadores de trabalhar — apesar de tudo o que possa acontecer e, especialmente, depois que tudo aconteça. [...]. Pois os cínicos não são burros e de vez em quando eles certamente veem a nulidade a que tudo leva. Seus aparatos psíquicos (seelisch) têm de se tornar elásticos o suficiente para incorporar, como um fator de sobrevivência, uma dúvida permanente sobre suas próprias atividades. Eles sabem o que estão fazendo, mas eles fazem isso porque, no curto prazo, a força das circunstâncias e o instinto de autopreservação estão falando a mesma língua, e eles estão lhes dizendo que isso tem de ser assim. [...]. O cinismo é uma falsa consciência esclarecida. É aquela consciência modernizada, infeliz, em que o esclarecimento tem trabalhado tanto com sucesso, quanto em vão. Ele aprendeu suas lições no esclarecimento, mas não as colocou, e provavelmente não era apto para colocá-las em prática. Abastada e miserável ao mesmo tempo, esta consciência já não se sente afetada por qualquer crítica da ideologia; sua falsidade já está reflexivamente amortecida (Sloterdijk, 200I, p. 5).

\section{Referências bibliográficas}

Adorno, T. W. (I950a). "Politics and economics in the interview material". In: The Authoritarian Personality. New York: Harper \& Brothers.

(1950b). "Prejudice in the interview material". In: The Authoritarian Personality. New York: Harper \& Brothers.

(195I). Teoria freudiana e modelo fascista de propaganda. Publicado originalmente em Psychoanalysis and the Social Sciences 3 (408-433). Traduzido por Francisco Rüdiger.

(2000). The psychological technique of Martin Luther Thomas' radio addresses. California: Stanford University Press.

(2004). "Sobre la relación entre sociología y psicologia". In: Escritos Sociológicos I. Obra Completa 8. Madrid: Ediciones Akal.

(2008). As estrelas descem à Terra. São Paulo: Editora UnesP.

Adorno, T. W., Frenkel-Brunsivik, E., Levinson, D. J., Sanford, N. (i95oa). "Introduction”. In: The Authoritarian Personality. New York: Harper \& Brothers.

(I950b). "The measurement of implicit antidemocratic trends". In: The Authoritarian Personality. New York: Harper \& Brothers.

Antunes, D. C. (20I4) Por um conhecimento sincero do mundo falso - Teoria crítica, pesquisa social empirica e The Authoritarian Personality. Jundaí: Paco Editorial.

Benjamin, J. (1977). “The end of internalization: Adorno's social psychology”. In: Telos, n. 32 , pp. $42-64$. 
Crochiк, L. (2000). “Tecnologia e individualismo: um estudo de uma das relaçóes contemporâneas entre ideologia e personalidade”. In: Análise Psicológica, n. 4 (xVIII), pp. 529-542.

Frenkel-Brunswik, E. (1950). "The interviews as an approach to the prejudiced personality". In: The Authoritarian Personality. New York: Harper \& Brothers.

Freud, S. (1992a). "Algunas consecuencias psíquicas de la diferencia anatómica entre los sexos". In: Obras completas - Volumen I9 (I923-25). Buenos Aires: Amorrortu editores.

(I992c). "La organización genital infantil (Una interpolación en la teoría de la sexualidad)". In: Obras completas - Volumen Ig (I923-25). Buenos Aires: Amorrortu editores.

(I992e). "Neurosis y psicosis". In: Obras completas - Volumen I9 (I923-25). Buenos Aires: Amorrortu editores.

Genel, K. (20I0). "L'approche sociopsychologique de Horkheimer, entre Fromm et Adorno." In: Astérion. v. 7 (agosto). Disponível em: <http://asterion.revues.org/I6II>. Acesso em: 6 dez. 2017.

Horkheimer, M. (1950). "Preface". In: The Authoritarian Personality. New York: Harper \& Brothers.

Horkheimer, M., Adorno, T. W. (1988). Dialektik der Aufklärung - Philosophische Fragmente. Frankfurt am Main: Fischer.

(1985). Dialética do Esclarecimento - Fragmentos Filosóficos. Rio de Janeiro: Jorge Zahar Editor.

Lebrun, J.-P. (2007). La perversion ordinaire - vivre sans autrui. Paris: Denoël.

Safatle, V. (2008). Cinismo e falência da crítica. São Paulo: Boitempo. (20Io). Fetichismo: Colonizar o Outro. Rio de Janeiro: Civilização Brasileira.

SANFORD, N. (1950). "Genetic aspects of the authoritarian personality: case studies of two contrasting individuals". In: The Authoritarian Personality. New York: Harper \& Brothers.

Sloterdijk, P. (200I). Critique of Cynical Reason. Minneapolis/London: University of Minnesota Press.

Stone, W. F., Lederer, G., Christie, R. (1992) (org) Strength and weakness: the authoritarian personality today. New York: Springer-Verlag.

Whiтевоок, J. (1995) Perversion and utopia - A Study in Psychoanalysis and Critical Theory. Cambridge/London: The miт Press.

Wiggershaus, R. (2002). A Escola de Frankfurt: história, desenvolvimento teórico, significação politica. Rio de Janeiro: DIFEL. 